\title{
Population genetic structure of North American burbot (Lota lota maculosa) across the Nearctic and at its contact zone with Eurasian burbot (Lota lota lota)
}

\author{
Kathryn R. Elmer, Jeroen K.J. Van Houdt, Axel Meyer, and Filip A.M. Volckaert
}

\begin{abstract}
The burbot, Lota lota (Teleostei: Gadidae), has a holarctic distribution, with one subspecies (Lota lota lota) living in the lakes and rivers of the Palaearctic and northwestern North America and the other (Lota lota maculosa) living in the Nearctic (except the northwest). We analysed nine microsatellite loci and the mitochondrial DNA control region of 350 burbot sampled across North America to develop a continent-wide understanding of population differentiation following postglacial recolonization. Using mitochondrial DNA, we identify three subclades of $L$. l. maculosa: one is widespread, one is moderately well distributed, and the third is restricted to the southwest. Lota l. lota is restricted to Yukon and Alaska. Microsatellite loci show moderate levels of genetic diversity and high population differentiation throughout North America $\left(R_{\mathrm{st}} \leq 0.9\right)$. Lota l. maculosa and L. l. lota mtDNA lineages only co-occur appreciably in Great Slave Lake. An individual-based Bayesian approach to detect genotypic admixture indicates that very few of all individuals show signs of admixture between subspecies, and those individuals are restricted to Great Slave Lake and Lake Laberge.

Résumé : L'aire de répartition de la Lotte, Lota lota (Teleostei : Gadidae), est circumpolaire avec une sous-espèce (Lota lota lota) vivant dans les lacs et rivières du paléarctique et le nord-ouest de l'Amérique du Nord, et l'autre sous-espèce (Lota lota maculosa) vivant dans le néarctique (sauf le nord-ouest). Nous avons analysé neuf microsatellites marqueurs génétiques et l'ADN mitochondrial (région de contrôle) des Lottes. Les échantillons nord-américains on été prélevés afin de comprendre la différenciation génétique de la population à traver tout le continent suite à la colonisation post-glaciaire. L'ADNmt identifie trois clades génétiques dans L. l. maculosa : une clade est très répandue, une autre est distribuée modérément, et la troisième se retrouve seulement dans la région du sud-ouest. Lota l. lota se retrouve seulement dans les territoires du Yukon et Alaska. Les marqueurs microsatellites montrent un niveau moyen en diversité génétique mais une différenciation génétique élevée entre populations à travers l'Amérique du Nord $\left(R_{\mathrm{st}} \leq 0,9\right)$. Les lignées ADNmt de $L$. l. maculosa et L. l. lota coexistent seulement dans le Grand lac des Esclaves. Une approche Bayesianne, basée sur les individus, dans le but de détecter le mélange génétypique, indique que peu des Lottes montrent un brassage génétique entre sous-espèces; ils se retrouvent seulement dans le Grand Lac des Esclaves et Lac Laberge.
\end{abstract}

\section{Introduction}

Ample genetic evidence is accumulating that the isolation of North American aquatic biota, including fish species, into separate refugia during glaciations and their subsequent postglacial secondary contact has been an influential element of species evolution and contemporary diversity and ecology (e.g., Bernatchez and Wilson 1998; Brunner et al. 2001; Turgeon and Bernatchez 2001). Most studies of postglacial secondary contact in the North American continent have focused on the level of glacial races (i.e., recent divergences). However, there is less information about the postglacial secondary contact of more deeply diverged lineages with contemporary parapatric distributions. The burbot, Lota lota (Teleostei: Gadidae), is a freshwater fish with a holarctic distribution. It is an excellent study organism to elucidate contemporary and regional genetic patterns in the broader evolutionary context of the entire species and its postglacial geographic distribution. Here we report on an investigation of the mitochondrial and nuclear genetic diversity of the burbot across its North American range and characterize the postglacial dynamics of a subspecies contact zone.

Advancing and receding glaciers during the Pleistocene have dramatically affected the distributional history of freshwater fish. During the Last Glacial Maximum, North America (except for much of Alaska) was covered in ice that

Received 11 March 2008. Accepted 8 August 2008. Published on the NRC Research Press Web site at cjfas.nrc.ca on 28 October 2008. J20462

K.R. Elmer and A. Meyer. ${ }^{1}$ Lehrstuhl für Zoologie und Evolutionsbiologie, Department of Biology, University of Konstanz, Universitätstraße 10, D-78457 Konstanz, Germany.

J.K.J. Van Houdt. Laboratory of Animal Diversity and Systematics, Katholieke Universiteit Leuven, Ch. Deberiostraat 32 , B-3000 Leuven, Belgium; Royal Museum of Central Africa, Leuvensesteenweg 13, B-3080 Tervuren, Belgium.

F.A.M. Volckaert. Laboratory of Animal Diversity and Systematics, Katholieke Universiteit Leuven, Ch. Deberiostraat 32, B-3000 Leuven, Belgium.

${ }^{1}$ Corresponding author (e-mail: axel.meyer@uni-konstanz.de). 
extended throughout Canada and the northern USA (Pielou 1991; Elias 2001; Glushkova 2001). When the Laurentide and Cordilleran ice sheets retreated with the subsiding glacial maximum, for thousands of years immense proglacial lakes formed, grew, shifted, and receded across northwestern North America (Pielou 1991; Lemmen et al. 1994). Deglaciation (10500 years ago) coupled with isostatic rebound (8500 years ago) formed the contemporary lakes of northwestern Canada, e.g., Great Slave Lake (Lemmen et al. 1994). Life, including fish, from the Beringian and southern refugia then had the opportunity to recolonize the harsh environments of North America that were previously thickly covered with ice (Pielou 1991). Population expansions due to increased habitat availability led to patterns of lineage sorting, secondary contact, and incipient speciation in a number of fish species (Schluter 2000).

The burbot lives in northern climates and inhabits deep, cold water in slow-running rivers and oligotrophic lakes. Adults prefer cold $\left(10-12{ }^{\circ} \mathrm{C}\right)$, well-oxygenated water and are quite sedentary most of the time, remaining often concealed in deep-water shelters when not foraging. However, during their highly synchronized winter spawning, adults migrate over very long distances (Breeser et al. 1988) to spawn in cold, shallow waters during the winter or early spring. Whether this spawning is aggregate or individual is not clear. Larvae are pelagic and occupy shallow littoral zones, though their life history and transition to benthic life varies depending on habitat (see McPhail 1997).

Burbot taxonomy has a history of division, reunification, and division again, from one species to up to three subspecies based on minor morphological and meristic variation (for detailed taxonomic history, see Van Houdt et al. 2003). Based on a circumpolar phylogeographic study, Van Houdt et al. (2003) identified two distinct lineages: a EurasianBeringian group, which stretches throughout the Palaearctic and east as far as northwestern Canada, and a North American group, which is distributed throughout the entire continent north of $40^{\circ}$ latitude, excluding Alaska. Given the little morphological and genetic differentiation (average $1.25 \% p$ distance at cytochrome $b$ ); Van Houdt et al. (2003) concluded that the burbot is a single species with a holarctic distribution, divided according to two historically recognized and parapatric lineages matching the morphological descriptions of L. lota lota (Eurasian-Beringian lineage) and L. lota maculosa (North American lineage).

We report here on an extensive phylogeographic survey based on mtDNA sequences and nine polymorphic microsatellite loci to determine levels of diversity within and among burbot populations and subspecies across North America and to infer demographic history. We use individual-based genetic analyses to quantify admixture at the population and individual level, with particular interest in the areas where the two subspecies' mtDNA lineages cooccur. We demonstrate that gene flow between L. lota subspecies is extremely limited or absent and localized to the north-northwestern region of North America.

\section{Materials and methods}

\section{Genetic data collection}

Burbot were collected at 19 localities from across its
North American range (Fig. 1; Table 1). Samples of fin clip or muscle tissue were stored in $95 \%$ ethanol. A total of 350 individuals were used for the present study. Genomic DNA was extracted after a proteinase $\mathrm{K}$ digestion using a standard high salt method and ethanol precipitation (Bruford et al. 1998).

We genotyped all 350 samples at 11 microsatellite loci (Llo1, Llo6, Llo7, Llo12, Llo13, Llo15, Llo16, Llo21, Llo26, Llo32, Llo34) following established methods (Sanetra and Meyer 2005). Loci were amplified in three separate multiplex reactions using a multiplex polymerase chain reaction (PCR) kit (Qiagen) following manufacturer's protocols and using $0.1-0.2 \mu \mathrm{mol} \cdot \mathrm{L}^{-1}$ of each primer per reaction. PCR product was diluted 1:10 and fragment lengths were analysed on an ABI 3130xl and sized by GeneScan-500 (ROX) size standard (Applied Biosystems). Genotypes were analysed and scored in GeneMapper 4.0 (Applied Biosystems). Unlike previous studies on European burbot (Sanetra and Meyer 2005; Barluenga et al. 2006), we found locus Llo32 to be frequently nonamplifying and excluded it from all analyses. Also, locus Llo13 was excluded because of poor reproducibility of scoring due to stutter bands.

We characterized approximately $450 \mathrm{bp}$ of the mitochondrial control region for 293 new samples and compiled previously published sequences for the remaining 57. Amplification followed published methods for burbot (Van Houdt et al. 2005). DNA sequences were determined by three different methods. In one, PCR product was cleaned with QIAquick PCR Purification Kit (Qiagen) following manufacturer's directions, and then sequencing reactions in each direction were prepared with BigDye Terminator Cycle Sequencing Ready Reaction Kit (Applied Biosystems). Product was analysed on an ABI 3130xl (Applied Biosystems) automated sequencer. In a second method, PCR product was purified with the GFX PCR DNA and Gel Band Purification kit (Amersham Biosciences) and sequenced with SequiTherm Excell II kit (Epicentres Technologies). The reactions were performed bidirectionally and products were analysed on an automatic sequencer LI-COR GeneReadIR DNA system (LI-COR). Third, we used a combination of single-strand conformation polymorphisms (SSCP) and endonuclease digestion to detect sequence variation in the $450 \mathrm{bp}$ fragment of the mitochondrial control region, according to the methodology described in Van Houdt et al. (2006).

\section{MtDNA data analyses}

Sequences were edited with 4Peaks (Griekspoor and Groothuis 2005) and assembled in MacClade (Maddison and Maddison 2003) or with Sequencher 4.2.2 (Gene Codes Corp.). The sequences were aligned using Clustal X with the default options (Thompson et al. 1997) and checked by eye. TCS 1.3 (Clement et al. 2000) and Network 4.2.0.1 (http:// www.fluxus-engineering.com) were used to build a statistical parsimony network (Templeton et al. 1992) and a median-joining network (Bandelt et al. 1999), respectively.

Diversity statistics and Fu's $F$ (Fu 1997) were calculated in DnaSP 4.10 .9 (Rozas et al. 2003). Significance of $F$ was assessed with coalescent simulations (1000 replicates) based on observed segregating sites. Mismatch analyses and raggedness indices were calculated in Arlequin 3.0 (Schneider 
Fig. 1. Sample localities of Lota lota across North America. The proportion of individuals with haplotypes related to each of the major mitochondrial lineages and refugial clades are noted in pie graphs by locality.

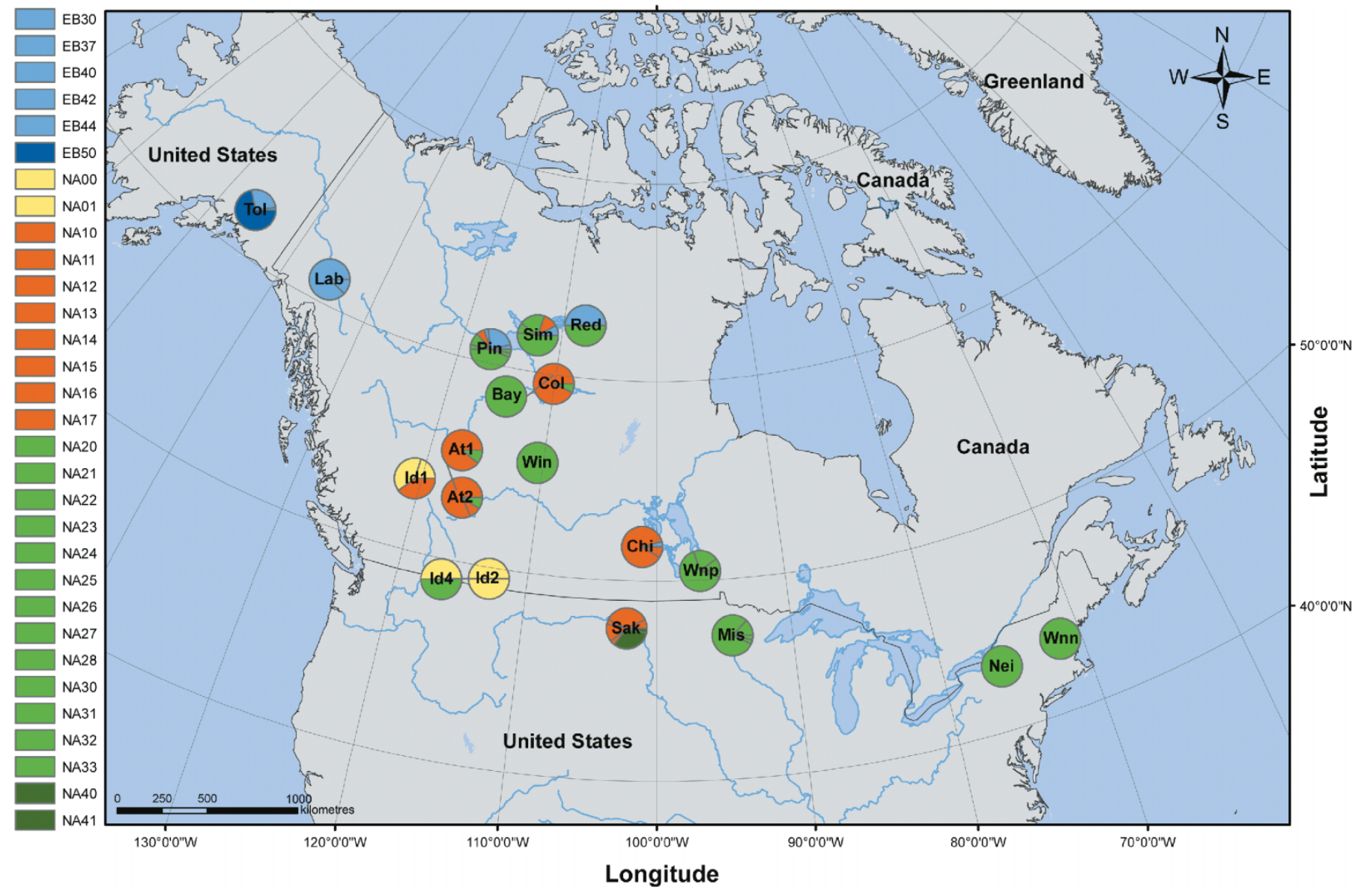

et al. 2000), and significance was assessed with 1000 bootstrap replicates.

\section{Population-based microsatellite analyses}

Hardy-Weinberg equilibrium by population and by locus and linkage disequilibrium were calculated in GENEPOP on the Web (Raymond and Rousset 1995) and a significance level of 0.05 was maintained through sequential Bonferroni correction (Rice 1989). Summary descriptive statistics (allele number and heterozygosity) were calculated in GENALEX 6.1 beta 2 (Peakall and Smouse 2006). In most cases, Great Slave Lake populations (GSL-Pin, GSL-Red, and GSLSim) are analysed together, and Id2 and Id4 are analyzed together, as the localities are close together and of the same waterbody (for sample localities and abbreviations, see Fig. 1 and Table 1).

To test whether allele size (as predicted by the stepwise mutation model, SSM) contributes significantly to the genetic differentiation of populations, or if differentiation is sufficiently characterized by differences in allele state (IAM, $F_{\text {st }}$ ), $R_{\text {st }}$ for all populations and individuals was permuted 10000 times in SPAGeDi (ver. 1.2; Hardy and Xavier 2002) and compared with observed $R_{\mathrm{st}}$. When $R_{\mathrm{st}}>\mathrm{p} R_{\mathrm{st}}$, allele size has a significant impact on genetic differentiation (Hardy et al. 2003).

We tested two hypotheses to explain the partitioning of microsatellite genetic variation among L. l. maculosa popu- lations using analysis of molecular variance based on $R_{\mathrm{ST}}$ calculated in GENALEX (excluding Tol, Lab, and singleton localities) by suppressing intra-individual analysis and using the "interpolate missing" option. First, we tested the importance of contemporary major watershed drainage (as inferred from Atlas of Canada, Geographía e Informática Instituto Nacional de Estadistica, and National Atlas of the United States 2006): Pacific draining (Id1, Id2, Id4), Arctic draining (GSL, Col, At1, At2), Hudson Bay draining (Chi, Wnp), Gulf of Mexico draining (Sak, Mis), and Atlantic draining (Nei). Second, we tested the importance of Pleistocene refugial group as estimated by Van Houdt et al. (2005): Mississippi clade (GSL, Mis, Nei, Wnp), Missouri clade (Sak, At1, At2, Col, Id1, Chi), and Pacific clade (Id2, Id4). Three of these localities (GSL, Wnp, Chi) were not included in the refugial clade analysis of Van Houdt et al. (2005), so we inferred their refugial clade based on the subclade of origin for the majority of haplotypes at the locality. Although the GSL locality has L. l. lota haplotypes, we include it in this microsatellite analysis because it has almost purely L. l. maculosa genotypes (see below). Significance was assessed with 999 permutations. Mantel's test of genetic distance $\left(F_{\mathrm{st}} /\left(1-F_{\mathrm{st}}\right)\right.$; Rousset 1997) versus straight-line geographic distance among $L$. l. maculosa populations was calculated in GENALEX and assessed with 999 permutations (excluding singleton populations, Tol, and Lab).

We tested for the possibility of a demographic expansion 
Table 1. Locality and sampling data of burbot (Lota lota) from North America.

\begin{tabular}{|c|c|c|c|c|c|}
\hline Population & Locality & Latitude $(\mathrm{N})$ & Longitude (W) & $N$ & mtDNA \\
\hline At1 & Athabasca River, Lambert Creek, Alberta & $53^{\circ} 30^{\prime}$ & $117^{\circ} 00^{\prime}$ & 9 & NA10(8), NA30(1) \\
\hline At 2 & Athabasca River, Lac Beauvert, Alberta & $52^{\circ} 55^{\prime}$ & $118^{\circ} 00^{\prime}$ & 11 & NA10(9), NA14(1), NA30(1) \\
\hline Bay & Bayonet Lake, Alberta & $59^{\circ} 56^{\prime}$ & $110^{\circ} 17^{\prime}$ & 1 & NA31(1) \\
\hline Chi & Child's Lake, Manitoba & $51^{\circ} 42^{\prime}$ & $101^{\circ} 11^{\prime}$ & 23 & EB37(1), NA16(20), NA17(2) \\
\hline Col & Colin Lake, Alberta & $59^{\circ} 33^{\prime}$ & $110^{\circ} 07^{\prime}$ & 14 & NA10(13), NA30(1) \\
\hline Id 1 & Goat River, British Colombia & $53^{\circ} 31^{\prime}$ & $120^{\circ} 35^{\prime}$ & 5 & NA00(1), NA01(2), NA13(2) \\
\hline $\mathrm{Lab}$ & Lake Laberge, Yukon & $61^{\circ} 11^{\prime}$ & $135^{\circ} 11^{\prime}$ & 16 & EB40(14), EB42(2) \\
\hline Mis & Leech Lake, Mississippi & $47^{\circ} 09^{\prime}$ & $94^{\circ} 25^{\prime}$ & 30 & $\begin{array}{l}\text { NA20(4), NA21(24), NA22(1), } \\
\text { NA23(1) }\end{array}$ \\
\hline Nei & Oneida Lake, New York & $43^{\circ} 10^{\prime}$ & $75^{\circ} 55^{\prime}$ & 33 & NA30(33) \\
\hline GSL-Pin & $\begin{array}{l}\text { Great Slave Lake (Pine Point), Northwest } \\
\text { Territories }\end{array}$ & $60^{\circ} 58^{\prime}$ & $114^{\circ} 23^{\prime}$ & 29 & $\begin{array}{l}\text { EB30(1), EB40(7), EB42(1), } \\
\text { NA10(2), NA20(2), NA27(1), } \\
\text { NA30(13), NA31(1), NA32(1) }\end{array}$ \\
\hline Sak & Missouri River, Sakakawea Lake & $47^{\circ} 37^{\prime}$ & $102^{\circ} 14^{\prime}$ & 28 & $\begin{array}{l}\text { NA10(2), NA11(10), NA12(1), } \\
\text { NA13(4), NA15(1), NA40(9), } \\
\text { NA41(1) }\end{array}$ \\
\hline Tol & Tolsona Lake, Alaska & $62^{\circ} 06^{\prime}$ & $146^{\circ} 04^{\prime}$ & 96 & EB40(2), EB42(25), EB50(69) \\
\hline Win & Winefred Lake, Alberta & $55^{\circ} 30^{\prime}$ & $110^{\circ} 31^{\prime}$ & 1 & NA30(1) \\
\hline Wnn & Winnisquam Lake, New Hampshire & $43^{\circ} 31^{\prime}$ & $71^{\circ} 29^{\prime}$ & 1 & NA24(1) \\
\hline Wnp & Lake Winnipeg (Winnipeg Beach), Manitoba & $50^{\circ} 28^{\prime}$ & $96^{\circ} 37^{\prime}$ & 20 & $\begin{array}{l}\text { NA20(2), NA24(4), NA25(13), } \\
\text { NA28(1) }\end{array}$ \\
\hline
\end{tabular}

Note: $N$, number of individuals sampled; mtDNA, haplotypes present, including their abundance (in parentheses).

in (i) L. l. maculosa (all populations excluding Tol, Lab, and GSL-Pin), (ii) all L. l. maculosa excluding the genetically and geographically more distant Nei population, (iii) L. l. lota (Tol and Lab), and (iv) Great Slave Lake, with two methods implemented in KGTESTS (Bilgin 2007). First, we tested within-locus $k$ to assess the allele-length distribution, which is expected to be unimodal in an expanding population (Reich and Goldstein 1998; Reich et al. 1999). The significance of $k$ is calculated according to a one-tailed binomial distribution (Bilgin 2007). Second, we calculated interlocus $g$ based on the expectation that the variance of the widths in the distribution of allele lengths will be markedly lower in an expanding population (Reich and Goldstein 1998; Reich et al. 1999). Significantly low $g$ is determined according to $5 \%$ percentile cutoff from simulations of $g$ values under constant population size (Reich et al. 1999; Table 1).

\section{Individual-based admixture microsatellite analyses}

Genetic admixture between the subspecies $L$. l. lota and L. l. maculosa at microsatellite loci was assessed using an individual-based Bayesian cluster approach as implemented in Structure 2.1 (Pritchard et al. 2000; Falush et al. 2003). We set $K=2$ to identify the proportion of membership $(Q)$ towards each of the two mitochondrial lineages (or subspecies). The analysis was executed with all 350 individuals and nine loci under a model of admixed ancestry among populations ( $\alpha$ inferred from the population data) and correlated allele frequencies (default $\lambda$ ). The first 50000 generations of the MCMC were discarded as burn-in and the following 150000 generations used to estimate $Q$. A $90 \%$ probability interval was used for individual admixture values. We ran the analysis five independent times to check for convergence on similar values. The five runs arrived at almost identical values of $\ln (P \mid D)$ and $Q$ $( \pm \leq 0.001)$ so we focus on the first run. A factorial correspondence analysis was calculated in GENETIX 4.05 (Belkhir et al. 1996) to partition the allelic variation in the data set into three-dimensional space.

\section{Results}

\section{MtDNA diversity and phylogeography}

A total of 31 haplotypes were identified, 25 in the North American (NA) lineage (L. l. maculosa subspecies) and six in the Eurasian-Beringian (EB) lineage ( $L$. l. lota subspecies). With 293 new sequences, 12 additional haplotypes (1 EB and 11 NA; GenBank accession numbers EU873154EU873165) augment previous research (Fig. 1; Table 1). The two subspecies lineages are separated by five mutations (not shown). Lota l. lota has a similar level of haplotype diversity as L. l. maculosa $(0.933 \pm 0.122$ compared with $0.990 \pm 0.014$, respectively) though a notably lower nucleotide diversity $(0.005 \pm 0.001$ compared with $0.011 \pm 0.001$, respectively) (Table 2 ).

The L. l. maculosa haplotypes resolve to three subclades, each separated by two mutations: Missouri (NA10-NA17), Pacific (NA00, NA01), and Mississippi (NA20-NA25, NA30-NA33, NA40-NA41) (Fig. 2a). mtDNA subclades are clearly genetically separated but are largely geographi- 
Fig. 2. Median-joining network of the genealogical relationships within mtDNA haplotypes of the subspecies (a) Lota l. maculosa and (b) Lota l. lota. The size of the circles is proportional to the haplotype frequency and colours are concordant with Fig. 1. The names of putative southern glacial refuges are noted next to subclades of L. l. maculosa. Grey L. l. lota haplotypes were not found in this study but are integral to network construction (Van Houdt et al. 2005).

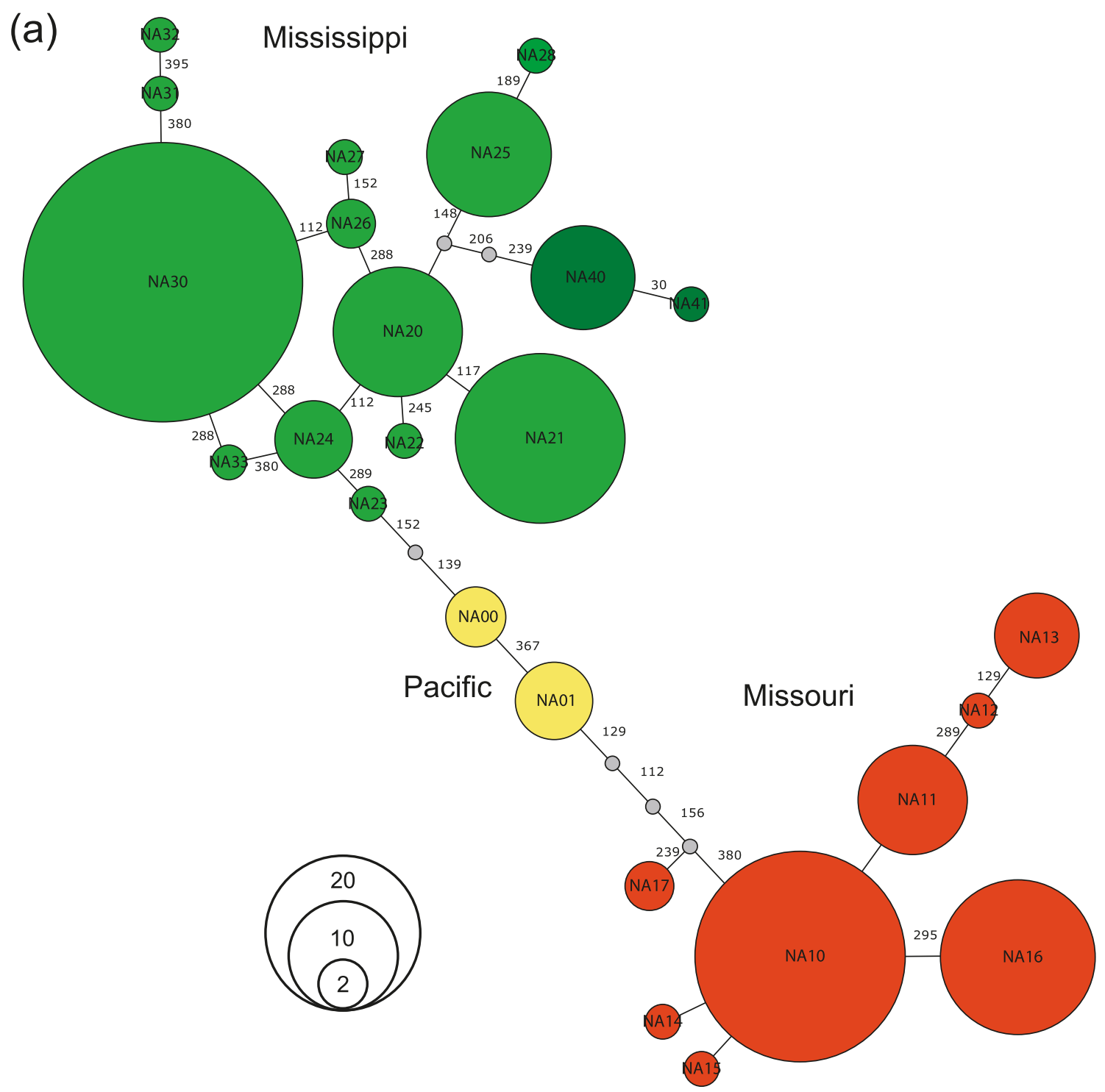

(b)

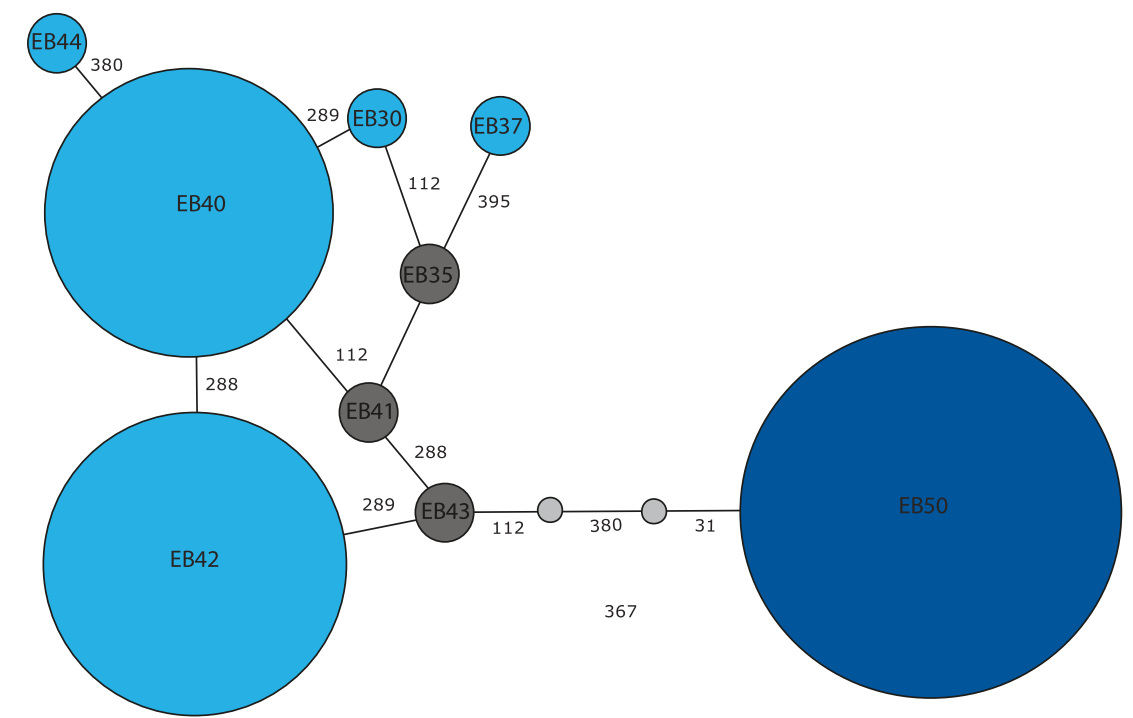


Table 2. Lota lota mitochondrial haplotype diversity statistics by subspecies.

\begin{tabular}{lrlllll}
\hline Subspecies & $n$ & $h$ & $\pi$ & SSD & $r$ & Fu's $F($ obs $)$ \\
\hline L. l. lota & 6 & $0.933 \pm 0.122$ & $0.005 \pm 0.001$ & $0.046 \mathrm{NS}$ & $0.187 \mathrm{NS}$ & $-1.846^{*}$ \\
L. l. maculosa & 25 & $0.990 \pm 0.014$ & $0.011 \pm 0.001$ & $0.012 \mathrm{NS}$ & $0.018 \mathrm{NS}$ & $-17.775^{*}$ \\
\hline
\end{tabular}

Note: $n$, number of haplotypes; $h$, haplotype diversity $( \pm \mathrm{SD}) ; \pi$, nucleotide diversity $( \pm \mathrm{SD}) ; \mathrm{SSD}$, mismatch
distribution sum of squared deviation; $r$, raggedness index; NS, $P>0.1 ; *, P<0.01$. Nonsignificant values of
SSD and $r$ suggest that the sudden expansion hypothesis cannot be rejected. Conversely, significantly nonzero
values of $F$ suggest population expansion.

cally overlapping (Fig. 1). The Mississippi subclade extends throughout the North American range but does not reach into Yukon and Alaska. The Pacific subclade is restricted to southwestern Canada. The Missouri subclade is distributed throughout the central and western portion of the range. The Mississippi subclade is the most diverse and has the greatest number of haplotypes (15), some at high abundance (e.g., NA30 and NA21), whereas the Pacific subclade has the fewest haplotypes (2) and they are at low abundance.

Lota l. lota haplotypes are found exclusively in the northnorthwestern portions of the North American continent (Tol, Lab, GSL-Pin, GSL-Red), except for one individual that was sampled in Manitoba (Chi) (Fig. 1; Table 1). The Alaska haplotype is restricted to Tol. Eight other EB haplotypes separated by one step are present in Tol, Lab, GSL-Pin, GSL-Red, and Chi (Figs. 1, 2b; Table 1). Haplotype EB50 is the most abundant, although EB40 is geographically more widespread. Thus, NA and EB haplotypes co-occur only in Great Slave Lake (localities GSL-Pin and GSL-Red) and the one EB haplotype in Chi, an area that is otherwise purely NA.

Mitochondrial haplotypes in both the L. l. lota and the L. l. maculosa subspecies show clear bimodal distributions of the occurrence and number of haplotype differences (Appendix A). Sum of squares deviations and raggedness are not significantly different from their expectation under a sudden population expansion (Table 2). Significantly negative values of Fu's $F$ also suggest expansion in both subspecies (Table 2) and within the L. l. maculosa subclades (Missouri, $F(\mathrm{obs})=-6.821, \quad P<0.001$; Mississippi, $F($ obs $)=-7.750, P<0.001 ;$ Pacific not assessed $)$.

\section{Microsatellite population equilibrium and diversity}

Interlocus tests of linkage disequilibrium (36 pairwise contrasts) are nonsignificant. Tests of Hardy-Weinberg proportions indicate no populations deviate significantly from equilibrium except Tol and GSL with all localities combined (Table 3), both due to a deviation from HWE at Llo34. When the three sample localities within GSL are considered separately, only GSL-Sim deviates significantly from HWE and at one locus. No other loci show any deviation from HWE (not shown).

Overall moderate levels of expected heterozygosity, ranging up to 0.75 in Great Slave Lake (Table 3), are found in most populations. By locus, Llo34 has the greatest allelic diversity with 38 alleles, and Llo7 has the fewest with seven (Appendix B; also Table 3). The distributions of allele sizes are notably different between $L$. $l$. maculosa and $L$. l. lota populations at many loci, though allele sizes overlap at all loci except Llo7 (Appendix B). Differences in allele size, not just state, are important to the differentiation between populations (Table 4): overall and at all loci except Llo1, Llo15, and Llo21, $R_{\mathrm{st}}$ is significantly greater than $\mathrm{p} R_{\mathrm{st}}$. Thus, in addition to drift, stepwise mutation has had a significant influence in accumulating genetic differentiation between populations. However, in this study, we often report both statistics to aid comparability with other studies.

Neither the $k$ test nor the $g$ test identified any significant signature of recent historical population expansion with $(i)$ all $L$. $l$. maculosa populations ( $k$ test $P=0.225 ; g=0.605$ ) or (ii) excluding the eastern region $(k$ test $p=0.225 ; g=$ 0.528). Tests on (iii) all L. l. lota populations and (iv) only Tolsona Lake did not suggest expansion either (iii: $k$ test $p=$ $0.225 ; g=1.011 ; i v$ : $k$ test $P=0.71 ; g=1.54)$. Finally, Great Slave Lake populations (GSL-Pin, GSL-Red, GSLSim) also did not show signs of recent population expansion ( $k$ test $p=0.225 ; g=1.216$ ).

\section{Microsatellite diversity between populations}

Population differentiation based on allelic identity $\left(F_{\text {st }}\right)$ and allele size $\left(R_{\mathrm{st}}\right)$ offer similar patterns of moderate to great genetic differentiation between populations (per Wright 1978) (Table 5). As measured by $R_{\text {st }}$, all populations are significantly different from each other except Chi and At1 and among Id1, Id2, and Id4. $R_{\text {st }}$ values range from 0 to 0.917 . Differentiation is significant between all populations as estimated by $F_{\text {st }}$, with values ranging from 0.046 to 0.419. The highest interpopulation differences are between Tol and Lab and all other populations. Within L. l. maculosa, Nei has the highest genetic differentiation from other populations. Sample localities within Great Slave Lake (GSL-Pin and GSL-Sim, excluding GSL-Pin because of small sample size) are not significantly genetically differentiated at $F_{\text {st }}\left(F_{\text {st }}=0.001 P>0.05\right)$, though they are weakly so at $R_{\mathrm{st}}\left(R_{\mathrm{st}}=0.028, P=0.03\right)$.

Analysis of molecular variance based on allele size $\left(R_{\mathrm{st}}\right)$ indicates that the genetic variation among samples can be better explained by contemporary watershed (among regions $15 \%\left(R_{\mathrm{rt}}=0.146, P=0.001\right)$, among populations within regions $18 \%\left(R_{\mathrm{sr}}=0.208, P=0.001\right)$, within populations $67 \%$ $\left.\left(R_{\mathrm{st}}=0.324, P=0.001\right)\right)$ than by putative refugial clade (among regions $0 \%\left(R_{\mathrm{rt}}=-0.007, P=0.987\right)$, among populations within regions $31 \%\left(R_{\mathrm{sr}}=0.311, P=0.001\right)$, within populations $\left.69 \%\left(R_{\mathrm{st}}=0.306, P=0.001\right)\right)$. To confirm that this is not an artefact of small southwestern sample sizes, we repeated the analyses excluding all Pacific individuals (Id1, Id2, Id4) and found no difference in relative importance of either description (watersheds: among regions 10\%, among populations within regions $19 \%$, within populations $71 \%$; refugia: among regions $0 \%$, among populations within regions $31 \%$, within populations $69 \%$ ).

Mantel's test of the correlation between interpopulation genetic differentiation and geographic distance indicates no 
Table 3. Number of alleles $\left(N_{\mathrm{a}}\right)$ and expected heterozygosity $\left(H_{\mathrm{e}}\right)$ across nine polymorphic microsatellite loci by burbot (Lota lota) population, with mean and standard error (SE) for each.

\begin{tabular}{|c|c|c|c|c|c|c|c|c|c|c|c|c|}
\hline & Llo1 & Llo6 & Llo7 & Llo12 & Llo15 & Llo16 & Llo21 & Llo26 & Llo34 & Mean & $\pm \mathrm{SE}$ & HWE \\
\hline \multicolumn{13}{|c|}{ Tol } \\
\hline$N_{\mathrm{a}}$ & 8 & 10 & 7 & 4 & 2 & 6 & 3 & 4 & 10 & 6.00 & 0.99 & \\
\hline$H_{\mathrm{e}}$ & 0.68 & 0.83 & 0.63 & 0.69 & 0.08 & 0.60 & 0.47 & 0.50 & 0.79 & 0.59 & 0.07 & $* * *$ \\
\hline \multicolumn{13}{|c|}{ Lab } \\
\hline$N_{\mathrm{a}}$ & 4 & 9 & 5 & 3 & 3 & 5 & 2 & 7 & 9 & 5.22 & 0.86 & \\
\hline$H_{\mathrm{e}}^{a}$ & 0.48 & 0.82 & 0.39 & 0.62 & 0.12 & 0.68 & 0.17 & 0.80 & 0.85 & 0.55 & 0.09 & NS \\
\hline \multicolumn{13}{|c|}{ GSL } \\
\hline$N_{\mathrm{a}}$ & 7 & 19 & 18 & 19 & 6 & 19 & 4 & 14 & 23 & 14.33 & 2.31 & \\
\hline$H_{\mathrm{e}}$ & 0.46 & 0.92 & 0.90 & 0.82 & 0.48 & 0.91 & 0.41 & 0.89 & 0.93 & 0.75 & 0.07 & $* * *$ \\
\hline \multicolumn{13}{|c|}{ Bay } \\
\hline$N_{\mathrm{a}}$ & 1 & 1 & 1 & 2 & 1 & 2 & 1 & 2 & 2 & 1 & 0.18 & \\
\hline$H_{\mathrm{e}}$ & 0.00 & 0.00 & 0.00 & 0.50 & 0.00 & 0.50 & 0.00 & 0.50 & 0.50 & 0.22 & 0.09 & - \\
\hline \multicolumn{13}{|c|}{ Col } \\
\hline$N_{\mathrm{a}}$ & 3 & 10 & 4 & 5 & 2 & 7 & 1 & 8 & 10 & 5.56 & 1.12 & \\
\hline$H_{\mathrm{e}}$ & 0.52 & 0.85 & 0.53 & 0.72 & 0.07 & 0.70 & 0.00 & 0.83 & 0.84 & 0.56 & 0.11 & NS \\
\hline \multicolumn{13}{|c|}{ Win } \\
\hline$N_{\mathrm{a}}$ & 2 & 2 & 2 & 1 & 2 & 1 & 1 & 0 & 1 & 1.33 & 0.24 & \\
\hline$H_{\mathrm{e}}$ & 0.50 & 0.50 & 0.50 & 0.00 & 0.50 & 0.00 & 0.00 & 0.00 & 0.00 & 0.22 & 0.09 & - \\
\hline \multicolumn{13}{|c|}{ At1 } \\
\hline$N_{\mathrm{a}}$ & 5 & 5 & 6 & 6 & 4 & 6 & 3 & 4 & 9 & 5.33 & 0.58 & \\
\hline$H_{\mathrm{e}}$ & 0.67 & 0.72 & 0.81 & 0.69 & 0.69 & 0.72 & 0.29 & 0.64 & 0.86 & 0.68 & 0.05 & NS \\
\hline \multicolumn{13}{|c|}{ At2 } \\
\hline$N_{\mathrm{a}}$ & 4 & 5 & 5 & 7 & 4 & 6 & 1 & 3 & 5 & 4.44 & 0.58 & \\
\hline$H_{\mathrm{e}}^{a}$ & 0.67 & 0.71 & 0.71 & 0.70 & 0.61 & 0.69 & 0.00 & 0.66 & 0.39 & 0.57 & 0.08 & NS \\
\hline \multicolumn{13}{|c|}{ Id1 } \\
\hline$N_{\mathrm{a}}$ & 3 & 6 & 3 & 2 & 1 & 3 & 1 & 2 & 3 & 2.67 & 0.50 & \\
\hline$H_{\mathrm{e}}^{a}$ & 0.46 & 0.76 & 0.34 & 0.32 & 0.00 & 0.41 & 0.00 & 0.44 & 0.41 & 0.35 & 0.08 & NS \\
\hline \multicolumn{13}{|c|}{ Id2/Id4 } \\
\hline$N_{\mathrm{a}}$ & 3 & 6 & 4 & 2 & 2 & 3 & 2 & 3 & 3 & 3.11 & 0.42 & \\
\hline$H_{\mathrm{e}}^{a}$ & 0.29 & 0.80 & 0.58 & 0.32 & 0.15 & 0.56 & 0.28 & 0.41 & 0.64 & 0.45 & 0.07 & NS \\
\hline \multicolumn{13}{|c|}{ Chi } \\
\hline$N_{\mathrm{a}}$ & 4 & 9 & 6 & 10 & 3 & 14 & 3 & 7 & 9 & 7.22 & 1.22 & \\
\hline$H_{\mathrm{e}}^{a}$ & 0.50 & 0.72 & 0.69 & 0.71 & 0.54 & 0.88 & 0.47 & 0.75 & 0.85 & 0.68 & 0.05 & NS \\
\hline \multicolumn{13}{|c|}{ Wnp } \\
\hline$N_{\mathrm{a}}$ & 4 & 14 & 11 & 13 & 8 & 15 & 3 & 10 & 12 & 10.00 & 1.41 & \\
\hline$H_{\mathrm{e}}$ & 0.40 & 0.75 & 0.78 & 0.87 & 0.60 & 0.89 & 0.28 & 0.83 & 0.89 & 0.70 & 0.08 & NS \\
\hline \multicolumn{13}{|c|}{ Sak } \\
\hline$N_{\mathrm{a}}$ & 6 & 14 & 7 & 11 & 5 & 15 & 3 & 14 & 20 & 10.56 & 1.88 & \\
\hline$H_{\mathrm{e}}$ & 0.40 & 0.84 & 0.78 & 0.76 & 0.68 & 0.87 & 0.57 & 0.89 & 0.93 & 0.75 & 0.06 & NS \\
\hline \multicolumn{13}{|c|}{ Mis } \\
\hline$N_{\mathrm{a}}$ & 6 & 14 & 6 & 12 & 5 & 14 & 2 & 11 & 13 & 9.22 & 1.50 & \\
\hline$H_{\mathrm{e}}$ & 0.50 & 0.88 & 0.76 & 0.77 & 0.49 & 0.91 & 0.03 & 0.83 & 0.82 & 0.67 & 0.09 & NS \\
\hline \multicolumn{13}{|l|}{ Nei } \\
\hline$N_{\mathrm{a}}$ & 6 & 16 & 9 & 9 & 5 & 11 & 2 & 9 & 12 & 8.78 & 1.37 & \\
\hline$H_{\mathrm{e}}$ & 0.56 & 0.91 & 0.75 & 0.84 & 0.61 & 0.69 & 0.27 & 0.68 & 0.87 & 0.69 & 0.07 & NS \\
\hline \multicolumn{13}{|c|}{ Wnn } \\
\hline$N_{\mathrm{a}}$ & 1 & 2 & 2 & 1 & 1 & 2 & 2 & 2 & 1 & 1.56 & 0.18 & \\
\hline$H_{\mathrm{e}}$ & 0.00 & 0.50 & 0.50 & 0.00 & 0.00 & 0.50 & 0.50 & 0.50 & 0.00 & 0.28 & 0.09 & - \\
\hline
\end{tabular}

significant relationship and a large variance in the scatter, though there is a trend of positive correlation (Mantel's $R_{x y}=0.199, P=0.203, R^{2}=0.040$; graph not shown).

\section{Genetic admixture between subspecies}

When all microsatellite data were analyzed in Structure under a two-cluster model to represent two lineages 
Table 4. Importance of allele size (SSM) or allele identity (IAM) in the mutation pattern of Lota lota microsatellite alleles.

\begin{tabular}{llllll}
\hline & $\begin{array}{c}\text { No. of } \\
\text { alleles }\end{array}$ & $R_{\text {st }}$ & $F_{\text {st }}$ & Mean $\mathrm{p} R_{\text {st }}$ & $P\left(R_{\mathrm{st}}>\mathrm{p} R_{\mathrm{st}}\right)$ \\
\hline All loci & & 0.682 & 0.231 & $0.218(0.121-0.346)$ & $*$ \\
Llo1 & 15 & 0.290 & 0.236 & $0.210(0.048-0.470)$ & NS \\
Llo6 & 25 & 0.221 & 0.095 & $0.094(0.021-0.210)$ & $*$ \\
Llo7 & 26 & 0.865 & 0.229 & $0.222(0.064-0.479)$ & $*$ \\
Llo12 & 28 & 0.512 & 0.197 & $0.195(0.050-0.394)$ & $*$ \\
Llo15 & 13 & 0.136 & 0.429 & $0.349(0.058-0.622)$ & NS \\
Llo16 & 29 & 0.495 & 0.179 & $0.175(0.039-0.377)$ & $*$ \\
Llo21 & 8 & 0.406 & 0.503 & $0.370(0.025-0.651)$ & NS \\
Llo26 & 20 & 0.537 & 0.217 & $0.211(0.038-0.512)$ & $*$ \\
Llo34 & 38 & 0.548 & 0.125 & $0.123(0.027-0.273)$ & $*$ \\
\hline
\end{tabular}

Note: Observed $R_{\mathrm{st}}$ is significantly higher than permuted ( $\mathrm{p} R_{\mathrm{st}}$; approximately equal to $F_{\mathrm{st}}$ ) overall and in six of nine loci.

(L. l. lota and L. l. maculosa), the sample localities assigned to each cluster strongly agreed with the known geographic range of the two subspecies. Tol and Lab in the northwest resolve into one cluster and all other localities in North America resolve into the other cluster (Fig. 3). The proportion of membership $(Q)$ toward a lineage (and $1-Q$ to the other lineage) indicates the level of admixture at the population level (Table 5) or individual level (Figs. 3 and 4) (Pritchard et al. 2000). We consider $Q<0.05$ or $Q>0.95$ to represent a lack of admixture (following Lutz-Carrillo et al. (2006) and a standard significance level of 5\%). We identified only two localities with significant contemporary genetic admixture between the two subspecies: Lab with $Q=0.096$ to L. l. maculosa (and consequently 0.904 to L. l. lota) and GSL-Pin with $Q=0.947$ to L. l. maculosa (therefore 0.053 to $L$. l. lota) (Table 6). When all Great Slave Lake is considered as a single population, there is no significant admixture between subspecies in the lake $(Q($ maculosa $)=0.969)$.

At the individual level across the entire North American range, exceedingly few individuals have significant genetic admixture at microsatellites (Fig. 3). Excluding the probability interval, $229(66 \%)$ individuals had a purely typical $L$. $l$. maculosa genotype profile and 106 (30\%) had a purely typical L. l. lota genotype. Looking exclusively at individuals sampled from the putative contact zone of Great Slave and Laberge lakes $(N=72)$, most individuals reveal a very low proportion of microsatellite admixture towards either subspecies (Fig. 4). Nineteen individuals in Lab and GSL have notable admixture $(Q>20 \%)$ when the $90 \%$ probability interval is included.

Nine individuals in GSL have L. l. lota mtDNA (haplotypes EB30, EB40, EB42, EB44) and nuclear microsatellite profiles characteristic of $L$. l. maculosa (i.e., $Q($ maculosa $)>$ 0.95, excluding PI). No individuals with L. l. maculosa mtDNA (i.e., NA haplotypes) have a microsatellite genotype profile characteristic of $L$. l. lota, though two individuals are relatively highly admixed $(Q=0.81 \pm 0.25, Q=0.73 \pm$ 0.28). In Chi, one individual has some microsatellite genetic admixture $(Q($ maculosa $)=0.80)$ and a $L$. l. maculosa mtDNA haplotype (NA16), whereas a different individual had a L. l. lota mtDNA (haplotype EB37) and is purely
L. l. maculosa at microsatellites $(Q($ maculosa $)=0.997 \pm$ $0.01)$.

FCA indicates that the first axis is responsible for $4.83 \%$ of the variance in the data. The two additional axes account for less than $2.6 \%$. Tolsona Lake is a clearly separate cloud from the remainder of the samples. Lake Laberge is located in three-dimensional space close to Tolsona Lake but also has some intermediate spread between Tolsona and the rest of the samples, reflecting its degree of admixture. Great Slave Lake populations are indistinguishable from the rest of the central region (figure not shown because of low explanatory power).

\section{Discussion}

\section{Postglacial history}

The subspecies L. l. lota and L. l. maculosa are genetically distinct at the mitochondrial and nuclear genome, as sampled by microsatellites, and show parapatric geographic distributions based on both markers. The evolutionary divergence between $L$. $l$. lota and $L$. $l$. maculosa well exceeds that of other temperate fish that have been isolated in recent glacial refuges because of the burbot's Pleistocene divergence ( 1 million years ago) (Van Houdt et al. 2003). Only with re-expansion eastward across the Palaearctic 240 or 130 thousand years ago did L. l. lota reach Beringia where it survived the Last Glacial Maximum, while L. l. maculosa survived glaciations in North America in southern refugia (Cumbaa et al. 1981; Van Houdt et al. 2003, 2005). Consequently, although genetic distance may be an imprecise metric by which to predict possible introgression in freshwater fish populations (Utter 2001), the 2\% divergence between L. l. lota and L. l. maculosa is higher than what is found between recent glacial lineages, which tend to be in the range of $0.7 \%$ to $1 \%$ mtDNA divergence (Turgeon and Bernatchez (2001) and references therein). There is a stark contrast between the very low admixture between subspecies in this study and the high levels of admixture found between central European glacial races. Danubian and Rhenan refugial burbot separated by three mtDNA control region mutations have completely admixed in Lake Constance, Germany, since the time of their secondary postglacial contact, maxi- 
Fig. 3. The apportionment of each individual's genotype to either Lota l. lota (open areas) or L. l. maculosa (solid areas), as determined by analysis in Structure. Population abbreviations follow Table 1.

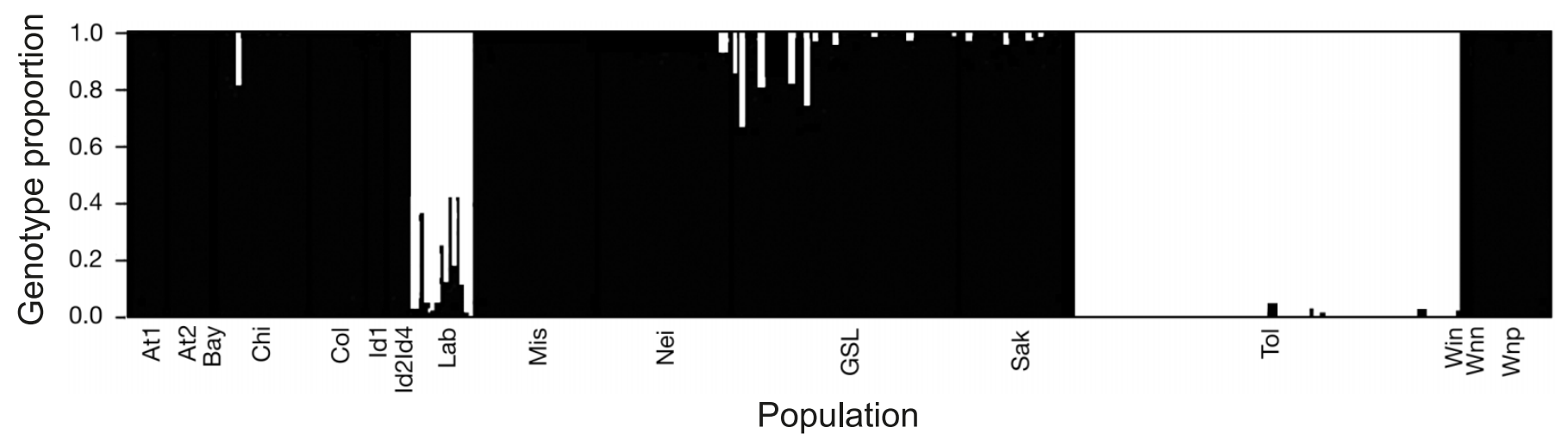

Fig. 4. The distribution of individual membership coefficients ( $Q \pm 90 \%$ probability intervals) of Lota l. maculosa characteristic genotypes in the lakes identified through our microsatellite analyses to have admixture: Lake Laberge and Great Slave Lake. Each sample along the $x$ axis represents an individual (open squares, EB haplotype; solid squares, NA haplotype). Individuals in GSL are ordered along the $x$ axis: GSL-Pin, GSL-Red, GSL-Sim. Individuals with high $y$-axis values have a high proportion of their sampled genotype representative of L. l. maculosa and those with low $y$-axis values have a low proportion of L. l. maculosa genotype, i.e., a high proportion of $L$. l. lota genotype.

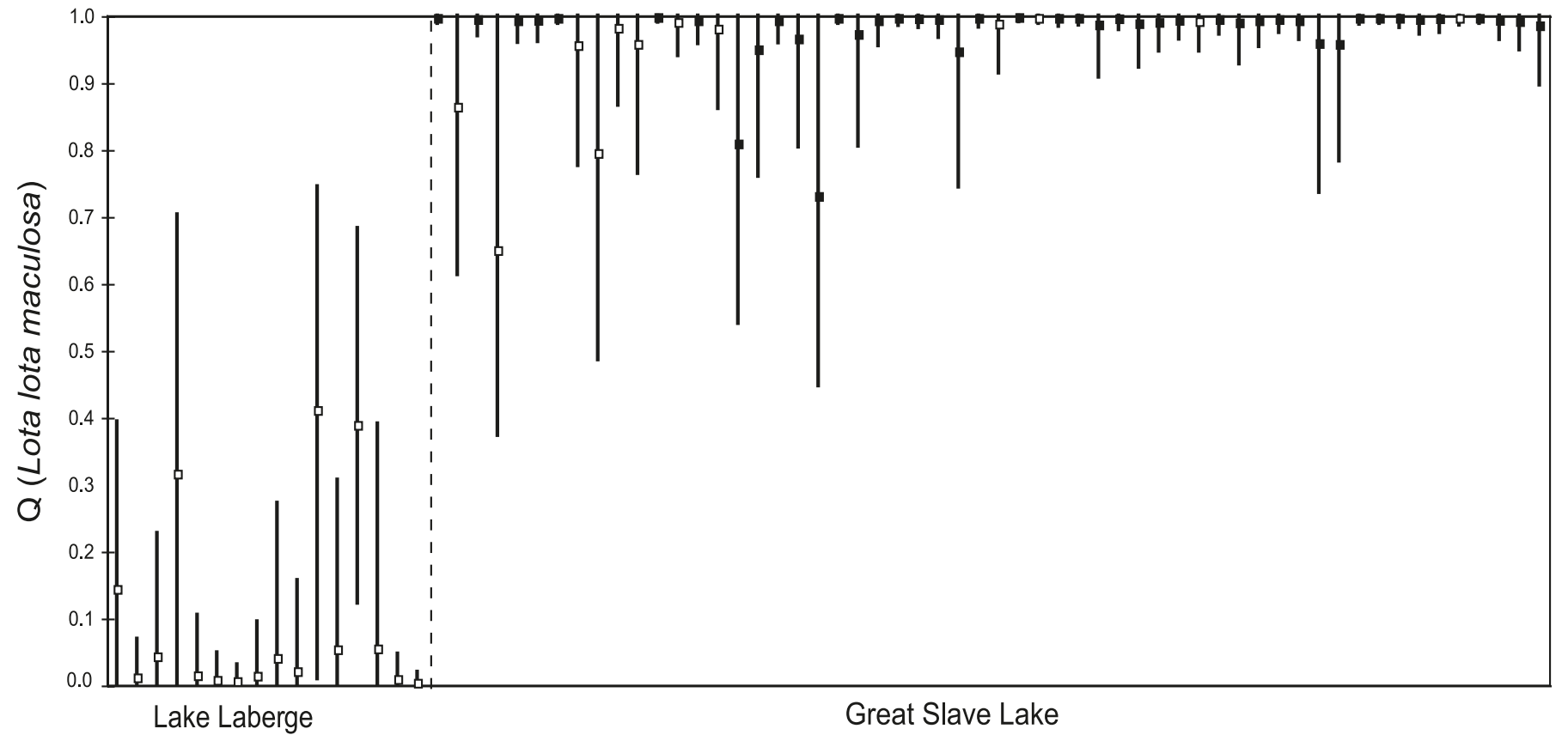

mally 15000 to 10000 years ago (Barluenga et al. 2006). Lota l. maculosa and L. l. lota are separated by five control region mutations (at a shorter, more variable portion of the mtDNA control region) yet show extremely low and localized levels of genetic admixture between them.

Many northern freshwater fish are known to have dispersed eastward from Beringia into North America with the retreat of the Laurentide ice sheet at the end of the last glaciation, including Arctic grayling (Thymallus arcticus; Stamford and Taylor 2004), lake whitefish (Coregonus clupeaformis; Bernatchez and Dodson 1991, 1994), lake trout (Salvelinus namaycush; Wilson and Hebert 1996, 1998), and Arctic char (Salvelinus alpinus; Wilson et al. 1996), as evidenced by molecular studies. However, other fish have not reinvaded so successfully after their isolation in Beringia (Lindsey and McPhail 1986; Bernatchez and Dodson 1994). Lota l. lota expanded only as far as northwestern Canada and has not invaded the rest of the continent, although there is very slight evidence (e.g., one mtDNA haplotype at Chi) for natural or anthropogenic dispersal further south. Lota l. maculosa must have expanded northward from the south, as its entire contemporary distribution was covered with ice in the previous glacial maximum and there is no evidence, molecular or zoogeographic, for its presence in the Beringian refuge (this study; McPhail 1997; Van Houdt et al. 2005). However, its range to the north is limited: genotypic data suggest very low levels of admixture and none further northwest than Lake Laberge (Lab) and no mtDNA co-occurrence except in Great Slave Lake (GSL) and no further north. Why this parapatry re- 
Table 5. Estimates of $R_{\text {st }}$ (below diagonal) and $F_{\text {st }}$ (above diagonal) for microsatellites for all populations of burbot (Lota lota).

\begin{tabular}{|c|c|c|c|c|c|c|c|c|c|c|c|c|c|}
\hline & Tol & $\mathrm{Lab}$ & GSL & $\mathrm{Col}$ & At1 & At2 & Id 1 & $\operatorname{Id} 2 \operatorname{Id} 4$ & Chi & Wnp & Sak & Mis & Nei \\
\hline Tol & & 0.216 & 0.275 & 0.396 & 0.329 & 0.348 & 0.370 & 0.367 & 0.307 & 0.331 & 0.287 & 0.346 & 0.306 \\
\hline Lab & 0.222 & & 0.268 & 0.408 & 0.342 & 0.371 & 0.419 & 0.386 & 0.300 & 0.333 & 0.260 & 0.338 & 0.255 \\
\hline GSL & 0.763 & 0.606 & & 0.105 & 0.066 & 0.144 & 0.221 & 0.182 & 0.065 & 0.046 & 0.070 & 0.068 & 0.153 \\
\hline At1 & 0.913 & 0.765 & 0.063 & 0.385 & & 0.169 & 0.276 & 0.247 & 0.129 & 0.110 & 0.117 & 0.123 & 0.220 \\
\hline At2 & 0.917 & 0.797 & 0.195 & 0.596 & 0.427 & & 0.349 & 0.318 & 0.190 & 0.203 & 0.194 & 0.210 & 0.272 \\
\hline Chi & 0.893 & 0.757 & 0.138 & 0.365 & 0.041 & 0.443 & 0.538 & 0.532 & & 0.115 & 0.116 & 0.132 & 0.199 \\
\hline Wnp & 0.909 & 0.793 & 0.124 & 0.497 & 0.156 & 0.234 & 0.601 & 0.580 & 0.202 & & 0.088 & 0.082 & 0.174 \\
\hline Sak & 0.877 & 0.747 & 0.118 & 0.315 & 0.257 & 0.324 & 0.474 & 0.489 & 0.257 & 0.173 & & 0.111 & 0.128 \\
\hline Mis & 0.890 & 0.776 & 0.151 & 0.237 & 0.242 & 0.441 & 0.483 & 0.483 & 0.210 & 0.256 & 0.055 & & 0.192 \\
\hline Nei & 0.905 & 0.806 & 0.315 & 0.544 & 0.492 & 0.414 & 0.511 & 0.518 & 0.561 & 0.402 & 0.366 & 0.454 & \\
\hline
\end{tabular}

Note: All differences are significant $(P<0.05)$ except the two noted in bold. According to analyses based on $R_{\mathrm{st}}$, all populations are significantly different except between Child's Lake (Chi) and Athabasca River (At1) and between the Kootenai River (Id) populations. All populations are significantly different from each other given $F_{\text {st }}$ analyses. There is no significant differentiation between the three localities (GSL-Pin, GSL-Red, GSL-Sim) within Great Slave Lake (GSL) (data not shown), so they are analysed here as a single population. Population abbreviations follow Table 1.

mains biologically is unclear (see later in Discussion), but historical physical geography could be responsible. Postglacial expansion of fish southward from Beringia may have been impeded by a now extinct waterfall on the lower Peel River. With the erosion of the waterfall, when Beringian fish finally arrived to the Mackenzie basin and Great Slave Lake area, they were competitively excluded by established populations of southern refuge fish (see Pielou 1991).

There is genetic indication of population expansion from southern (L. l. maculosa) and northern (L. l. lota) refugia at mitochondrial but not nuclear markers. The shape of the haplotype networks (some widespread haplotypes and abundant central haplotypes), mismatch analyses of pairwise differences, and Fu's $F$ all suggest demographic expansion from mtDNA. Lack of signal for expansion at microsatellites may be due to the conservativeness of the tests or lack of power with this number of loci (Reich et al. 1999). Historical population expansion is notoriously difficult to infer and is strongly influenced by population subdivision (Ray et al. 2003), which may explain the inconclusiveness of the expansion signal in this and previous (Van Houdt et al. 2005) studies. Given that most of the contemporary range of L. l. maculosa was covered with ice until 10000 to 12000 years ago, range expansion is certain but accompanying demographic expansion is less conclusive.

\section{Phylogeography and gene flow in L. l. maculosa}

Within the subspecies L. l. maculosa, the mtDNA genetic signatures of three southern glacial refugia are present, consistent with and augmenting some previous genetic studies (Van Houdt et al. 2003, 2005) and expectations based on zoogeography and Pleistocene glacial dynamics (Crossman and McAllister 1986; McPhail 1997). Haplotypes from the southern glacial refugia are generally geographically widespread: the Mississippi subclade is the most diverse and its haplotypes are found throughout North America excluding Yukon and Alaska; Missouri subclade haplotypes are found throughout the central and western portion of the range up to Great Slave Lake; and the Pacific subclade is restricted to the Columbia River drainage in southwestern Canada.
Divergence between subclades is low and each is separated by one or two mutations. The greater diversity found in the Mississippi subclade suggests that it harboured larger refugial population sizes during the Last Glacial Maximum relative to the other two refugia (Avise 2000). These three southern refugia are the source of many North American fish postglacial expansions (Rempel and Smith 1998; summarized in Turgeon and Bernatchez 2001; Stamford and Taylor 2004). Their exact location can only be generally known and surely varied during different times in glacial history (Bernatchez 1997; Rempel and Smith 1998). The southern glacial refugia currently intermix substantially in the previously glaciated areas, though they retain the geographical and genetic signal of history in mtDNA.

However, the genetic signal of microsatellites reflects more contemporary population distributions of $L$. l. maculosa. By far the greatest source of genetic variation is among contemporary watersheds rather than differentiation derived from historical refugia. There is no clear support that microsatellites maintain the relict genetic structure of the three southern glacial refugia. Further, at mtDNA, there is no evidence for a distinct burbot type in the Lake Erie watershed (Nei) (as suggested by Snyder (1979) and as previously also demonstrated in Van Houdt et al. (2003)). Microsatellite analyses suggest moderately high genetic differentiation between the east and the rest of $L$. l. maculosa, but this may be an artefact of remoteness. It is certainly much lower than the differentiation found between subspecies and is on par with some other interpopulation $R_{\mathrm{st}}$ contrasts.

The lack of significant population isolation-by-distance at microsatellites suggests that there is little equilibrium relationship between genetic and geographic distance (Rousset 1997; Hutchison and Templeton 1999). Because burbot is a good disperser (Breeser et al. 1988; Barluenga et al. 2006), this relationship may be particularly nonlinear; geographically proximate populations may nonetheless be in different water drainages, which impedes contemporary migration and disrupts the relationship between geographic distance and gene flow (McRae 2006). This is most obvious, for example, between populations west versus east of the continental di- 
Table 6. Mean membership coefficients $(Q)$ for microsatellite genotypes and proportion of each mtDNA lineage found in each population of burbot.

\begin{tabular}{llllll}
\hline & \multicolumn{2}{l}{ Microsatellites } & & mtDNA & \\
\cline { 2 - 3 } \cline { 5 - 6 } Population & L. l. lota & L. l. maculosa & & L. l. lota & L. l. maculosa \\
\hline At1 & 0.009 & 0.991 & 0 & 1 \\
At2 & 0.005 & 0.995 & 0 & 1 \\
Bay & 0.005 & 0.995 & 0 & 1 \\
Chi & 0.014 & 0.986 & $\mathbf{0 . 0 4 3}$ & $\mathbf{0 . 9 5 7}$ \\
Col & 0.003 & 0.997 & 0 & 1 \\
Id1 & 0.012 & 0.988 & 0 & 1 \\
Id2 & 0.005 & 0.995 & 0 & 1 \\
Id4 & 0.005 & 0.995 & 0 & 1 \\
Lab & $\mathbf{0 . 9 0 4}$ & $\mathbf{0 . 0 9 6}$ & 1 & 0 \\
Mis & 0.005 & 0.995 & 0 & 1 \\
Nei & 0.010 & 0.990 & 0 & 1 \\
GSL & 0.031 & 0.969 & $\mathbf{0 . 2 1 4}$ & $\mathbf{0 . 7 8 6}$ \\
Sak & 0.011 & 0.989 & 0 & 1 \\
Tol & 0.997 & 0.003 & 1 & 0 \\
Win & 0.005 & 0.995 & 0 & 1 \\
Wnn & 0.010 & 0.990 & 0 & 1 \\
Wnp & 0.007 & 0.993 & 0 & 1 \\
\cline { 1 - 1 }
\end{tabular}

Note: Admixed populations are noted in bold and defined as those with $Q<0.95$ for microsatellites and frequency $<1$ for mtDNA. GSL includes the three localities GSL-Pin, GSL-Red, and GSL-Sim. Population abbreviations are given in Table 1. Only Lab is admixed for microsatellites, and only GSL and Chi have both mtDNA lineages co-occurring. Note that the microsatellite admixture is calculated at the population level, while mtDNA admixture refers to the frequency of Lota l. lota (EB lineage) or L. l. maculosa (NA lineage) mtDNA in individuals in the population.

vide in Canada (Id1, Id2, and Id4 versus all other L. l. maculosa localities) and the northeastern-draining Manitoba populations (Chi, Wnp) versus those draining south (Sak, Mis).

\section{Admixture between burbot subspecies: historical and contemporary signals}

Patterns of genetic and geographic isolation between the two subspecies are generally concordant between mtDNA and microsatellites: both indicate that the Alaskan population (Tol) is purely L. l. lota and that all North American populations south of Great Slave Lake are purely L. l. maculosa (Table 6). Matrilineally inherited mtDNA and biparentally inherited microsatellites differ, however, in the scope of admixture that they indicate between subspecies in the contact zone. At Lake Laberge (Lab), there are low levels of population-level genetic admixture at microsatellites: $10 \%$ characteristic of L. l. maculosa and $90 \%$ L. l. lota. However, at the mitochondrial genome, the lake is purely L. l. lota. Within Great Slave Lake, burbot genotypes are purely characteristic (97\%) of L. l. maculosa. Nonetheless, there is mitochondrial geographic co-occurrence and a higher frequency of $L$. l. lota mitochondrial haplotypes (21\%) found in Great Slave Lake than there is evidence for nuclear genome admixture (3\%). Further, at Great Slave Lake, there are some individuals that are genotypically L. l. maculosa although they carry L. l. lota mtDNA; no examples of the reverse phenomenon are found, which may indicate differential introgression or asymmetric mating (Redenbach and Taylor 2003). A few moderately genotypically admixed individuals are found in Laberge and Great Slave lakes. There is one weakly admixed individual in Child's Lake, where the lineages of both subspecies co-occur. Neither genotypic admixture nor mitochondrial lineage co-occurrence is found anywhere else in North America.

The very low levels of microsatellite admixture at the individual level and the introgression of mtDNA across subspecies boundaries strongly suggest low-frequency historical hybridization events between $L$. $l$. lota and L. l. maculosa followed by repeated backcrosses into the parental population. We cannot determine from this study whether this is due to historical matings between subspecies followed by contemporary isolation (genetic, ecological, or geographic) or to occasional contemporary admixture between subspecies. However, the lack of first-generation subspecies hybrids (individuals with membership coefficients of approximately 0.5 and either mtDNA lineage) and the lack of linkage disequilibrium at nuclear loci suggest that there is little or no contemporary random mating between individuals of different subspecies at the contact zone (Barton and Hewitt 1985).

\section{Ecological parapatry and subspecies differences}

Ecological parapatry, or the abutting distributions of two different but closely related taxa, is often difficult to identify without extensive study because it requires detailed geographic and genetic data of morphologically similar taxa (Bull 1991). It is commonly the result of secondary contact between differentiating taxa when some mechanism such as ecological exclusion or variation in environment prevents their overlap. Isolation has been identified in other postglacial populations that do not mix contemporarily between historical southern and Beringian refugia (Pielou 1991; 
Rhymer et al. 2001; Fedorov et al. 2003), though subspecies of closely related temperate fish are often found to interbreed freely at contact zones (reviewed in Utter 2001; Lutz-Carrillo et al. 2006; Taylor et al. 2007). In fact, interbreeding when no geographic barrier prevails is fundamental to the definition of fish subspecies (Nelson 1999; Haig et al. 2006). With parapatrically distributed taxa with very low levels of admixture, such as in L. lota, it is difficult to discern if the forms remain distinct because of different environmental adaptations or poor hybrid fitness (Bull 1991). It remains possible that burbot subspecies interbreed more frequently than is suggested by our findings, but hybrids do not survive equally well to adulthood and are not represented. However, we never find two different genetic subspecies in the same lake, which strongly suggests that there is little contemporary contact between the parapatric subspecies' distributions.

There is only limited evidence for ecological differences between burbot subspecies. Morphologically, North American populations have been found to have a shorter and higher caudal peduncle, whereas Eurasian (excluding western Europe) and Beringian burbot have a longer, more narrow caudal peduncle (Pivnicka 1970; reviewed in Van Houdt et al. 2003). Caudal peduncle is an ecologically important trait: a long, low caudal peduncle is a particular adaptation to open water and acceleration, whereas a short, high caudal peduncle is better suited to manoeuvrability (Wootton 1991). Burbot from western Europe have a caudal peduncle more like North American burbot, so the morphological differences and similarities were attributed to similarities of climate (Pivnicka 1970) or perhaps lentic-lotic water adaptations within North America (Fisher et al. 1996). However, Van Houdt et al. (2003) suggested that within L. l. lota, caudal peduncle instead reflects common refugial history. Future studies of burbot L. l. lota and L. l. maculosa in northwestern Canada would benefit by including morphological and meristic characters to better elucidate the biological reality of the subspecies' genetic contact zone that we have located.

\section{Acknowledgements}

This research was funded by grants from the Deutsche Forschungsgemeinschaft and Sonderforschungsbereichs 454 to A.M., an Alexander von Humboldt Fellowship to K.R.E., and an Institute for Scientific and Technological Research (IWT) fellowship to J.V.H. We thank C. Johnson, A. Arndt, M. Steinhilber, V. Paragamian, S. Thomson, S. Fisher, T. VanDeValk, G. Low, P. Taylor, L. Perry-Plake, M. Racine, and W.Franzin for providing samples. K.R.E. thanks M. Sanetra and M. Barluenga for protocols and S. Boekhoff and H. Recknagel for laboratory assistance. The manuscript was improved by thoughtful comments from M. Sanetra and two anonymous reviewers.

\section{References}

Atlas of Canada, Geographía e Informática Instituto Nacional de Estadistica, and National Atlas of the United States. 2006. Watersheds of North America. Commission for Environmental Cooperation, Montréal, Québec, Canada.

Avise, J.C. 2000. Phylogeography: the history and formation of species. Harvard University Press, Cambridge, Mass.

Bandelt, H.J., Forester, P., and Röhl, A. 1999. Median-joining net- works for inferring intraspecific phylogenies. Mol. Biol. Evol. 16: 37-48. PMID:10331250.

Barluenga, M., Sanetra, M., and Meyer, A. 2006. Genetic admixture of burbot (Teleostei: Lota lota) in Lake Constance from two European glacial refugia. Mol. Ecol. 15: 3583-3600. doi:10.1111/j.1365-294X.2006.03045.x. PMID:17032259.

Barton, N.H., and Hewitt, G.M. 1985. Analysis of hybrid zones. Annu. Rev. Ecol. Syst. 16: 113-148. doi:10.1146/annurev.es.16. 110185.000553.

Belkhir, K., Borsa, P., Chikhi, L., Raufaste, N., and Bonhomme, F. 1996. GENETIX 4.05, logiciel sous Windows ${ }^{\mathrm{TM}}$ pour al génétique de populations. Laboratoire Génome, Populations, Interactions, CNRS UMR 5000 Université de Montpellier II, Montpellier, France.

Bernatchez, L. 1997. Mitochondrial DNA analysis confirms the existence of two glacial races of rainbow smelt Osmerus mordax and their reproductive isolation in the St. Lawrence River estuary (Québec, Canada). Mol. Ecol. 6: 73-83. doi:10.1046/j. 1365-294X.1997.00156.x.

Bernatchez, L., and Dodson, J.J. 1991. Phylogeographic structure in mitochondrial DNA of the lake whitefish (Coregonus clupeaformis) and its relation to Pleistocene glaciations. Evolution, 45: 1016-1035. doi:10.2307/2409706.

Bernatchez, L., and Dodson, J.J. 1994. Phylogenetic relationships among Palearctic and Nearctic whitefish (Coregonus sp.) populations as revealed by mitochondrial DNA variation. Can. J. Fish. Aquat. Sci. 51: 240-251. doi:10.1139/f94-310.

Bernatchez, L., and Wilson, C.C. 1998. Comparative phylogeography of Nearctic and Palearctic fishes. Mol. Ecol. 7: 431-452. doi:10.1046/j.1365-294x.1998.00319.x.

Bilgin, R. 2007. KGTESTS: a simple Excel Macro program to detect signatures of population expansion using microsatellites. Mol. Ecol. Notes, 7: 416-417. doi:10.1111/j.1471-8286.2006. 01671.x.

Breeser, S.W., Stearns, F.D., Smith, M.W., West, R.L., and Reynolds, J.B. 1988. Observations of movements and habitat preferences of burbot in an Alaskan glacial river system. Trans. Am. Fish. Soc. 117: 506-509. doi:10.1577/1548-8659(1988) 117<0506:OOMAHP>2.3.CO;2.

Bruford, M.W., Hanotte, O., Brookfield, J.F.Y., and Burke, T. 1998. Multi-locus and single-locus DNA fingerprinting. In Molecular genetic analysis of populations. Edited by A.R. Hoezel. Oxford University Press, New York. pp. 283-336.

Brunner, P.C., Douglas, M.R., Osinov, A., Wilson, C.C., and Bernatchez, L. 2001. Holarctic phylogeography of Arctic charr (Salvelinus alpinus L.) inferred from mitochondrial DNA sequences. Evolution, 55: 573-586. doi:10.1554/0014-3820(2001) 055[0573:HPOACS]2.0.CO;2. PMID:11327164.

Bull, C.M. 1991. Ecology of parapatric distributions. Annu. Rev. Ecol. Syst. 22: 19-36. doi:10.1146/annurev.es.22.110191.000315.

Clement, M., Posada, D., and Crandall, K.A. 2000. TCS: a computer program to estimate gene genealogies. Mol. Ecol. 9: 16571659. doi:10.1046/j.1365-294x.2000.01020.x. PMID:11050560.

Crossman, E.J., and McAllister, D.E. 1986. Zoogeography of freshwater fishes of the Hudson Bay drainage, Ungava Bay and the Arctic Archipelago. In The zoogeography of North American freshwater fishes. Edited by C.H. Hocutt and E.O. Wiley. John Wiley and Sons, New York. pp. 53-103.

Cumbaa, S.L., McAllister, D.E., and Morlan, R.E. 1981. Late Pleistocene fish fossils of Coregonus, Stenodas, Thymallus, Catostomus, Lota and Cottus from the Old Crow Basin, northern Yukon, Canada. Can. J. Earth Sci. 18: 1740-1754. doi:10.1139/ e81-159.

Elias, S.A. 2001. Beringian paleoecology: results from the 1997 
workshop. Quat. Sci. Rev. 20: 7-13. doi:10.1016/S0277-3791(00) 00135-9.

Falush, D., Stephens, M., and Pritchard, J.K. 2003. Inference of population structure using multilocus genotype data: linked loci and correlated allele frequencies. Genetics, 164: 1567-1587. PMID:12930761.

Fedorov, V.B., Goropashnaya, A.V., Jaarola, M., and Cook, J.A. 2003. Phylogeography of lemmings (Lemmus): no evidence for postglacial colonization of Arctic from the Beringian refugium. Mol. Ecol. 12: 725-731. doi:10.1046/j.1365-294X.2003.01776. x. PMID:12675827.

Fisher, S.J., Willis, D.W., and Pope, K.L. 1996. An assessment of burbot (Lota lota) weight-length data from North American populations. Can. J. Zool. 74: 570-575. doi:10.1139/z96-063.

Fu, Y.-X. 1997. Statistical tests of neutrality of mutations against population growth, hitchhiking and background selection. Genetics, 147: 915-925. PMID:9335623.

Glushkova, O.Y. 2001. Geomorphological correlation of Late Pleistocene glacial complexes of Western and Eastern Beringia. Quat. Sci. Rev. 20: 405-417. doi:10.1016/S0277-3791(00)00108-6.

Griekspoor, A., and Groothuis, T. 2005. 4Peaks, version 1.6. Available from mekentosj.com.

Haig, S.M., Beever, E.A., Chambers, S.M., Draheim, H.M., Dugger, B.D., Dunham, S., Elliott-Smith, E., Fontaine, J.B., Kesler, D.C., Knaus, B.J., Lopes, I.F., Loschl, P., Mullins, T.D., and Sheffield, L.M. 2006. Taxonomic considerations in listing subspecies under the U.S. Endangered Species Act. Conserv. Biol. 20: 1584-1594. doi:10.1111/j.1523-1739.2006.00530.x. PMID: 17181793.

Hardy, O.J., and Xavier, V. 2002. SPAGeDi: a versatile computer program to analyse spatial genetic structure at the individual or population levels. Mol. Ecol. Notes, 2: 618-620. doi:10.1046/j. 1471-8286.2002.00305.x.

Hardy, O.J., Charbonnel, N., Fréville, H., and Heuertz, M. 2003. Microsatellite allele sizes: a simple test to assess their significance on genetic differentiation. Genetics, 163: 1467-1482. PMID: 12702690.

Hutchison, D.W., and Templeton, A.R. 1999. Correlation of pairwise genetic and geographic distance measures: inferring the relative influences of gene flow and drift on the distribution of genetic variability. Evolution, 53: 1898-1914. doi:10.2307/ 2640449.

Lemmen, D.S., Duk-Rodkin, A., and Bednarski, J.M. 1994. Late glacial drainage systems along the northwestern margin of the Laurentide ice sheet. Quat. Sci. Rev. 13: 805-828. doi:10.1016/ 0277-3791(94)90003-5.

Lindsey, C.C., and McPhail, J.D. 1986. Zoogeography of fishes of the Yukon and Mackenzie basins. In The zoogeography of North American freshwater fishes. Edited by C.H. Hocutt and E.O. Wiley. John Wiley and Sons, New York. pp. 639-674.

Lutz-Carrillo, D.J., Nice, C.C., Bonner, T.H., Forstner, M.R.J., and Fries, L.T. 2006. Admixture analysis of Florida largemouth bass and northern largemouth bass using microsatellite loci. Trans. Am. Fish. Soc. 135: 779-791. doi:10.1577/T04-221.1.

Maddison, D.R., and Maddison, W.P. 2003. MacClade 4: analysis of phylogeny and character evolution. Version 4.07. Sinauer Associates, Sunderland, Mass..

McPhail, J.D. 1997. A review of burbot (Lota lota) life history and habitat use in relation to compensation and improvement opportunities. Can. Manuscr. Rep. Fish. Aquat. Sci. No. 2397, Department of Fisheries and Oceans, Canada. Available from http:// www.dfo-mpo.gc.ca/Library/211043.pdf.

McRae, B.H. 2006. Isolation by resistance. Evolution, 60: 15511561. PMID:17017056.
Nelson, J.S. 1999. The species concept in fish biology. Editorial and Introduction. Rev. Fish Biol. Fish. 9: 277-280. doi:10.1023/ A:1008976411673.

Peakall, R., and Smouse, P.E. 2006. GENALEX 6: genetic analysis in Excel. Population genetic software for teaching and research. Mol. Ecol. Notes, 6: 288-295. doi:10.1111/j.1471-8286.2005. 01155.x.

Pielou, E.C. 1991. After the Ice Age: the return of life to glaciated North America. University of Chicago Press, Chicago, Illinois.

Pivnicka, K. 1970. Morphological variation in the burbot (Lota lota) and recognition of the subspecies: a review. J. Fish. Res. Board Can. 27: 1757-1765.

Pritchard, J.K., Stephens, M., and Donnelly, P. 2000. Inference of population structure using multilocus genotype data. Genetics, 155: 945-959. PMID:10835412.

Ray, N., Currat, M., and Excoffier, L. 2003. Intra-deme molecular diversity in spatially expanding populations. Mol. Biol. Evol. 20: 76-86. doi:10.1093/molbev/msg009. PMID:12519909.

Raymond, M., and Rousset, F. 1995. GENEPOP, version 1.2: population genetics software for exact tests and ecumenicism. J. Hered. 86: 248-249.

Redenbach, Z., and Taylor, E.B. 2003. Evidence for bimodal hybrid zones between two species of char (Pisces: Salvelinus) in northwestern North America. J. Evol. Biol. 16: 1135-1148. doi:10.1046/j.1420-9101.2003.00619.x. PMID:14640405.

Reich, D.E., and Goldstein, D.B. 1998. Genetic evidence for a Paleolithic human population expansion in Africa. Proc. Natl. Acad. Sci. U.S.A. 148: 1921-1930.

Reich, D.E., Feldman, M.W., and Goldstein, D.B. 1999. Statistical properties of two tests that use multilocus data sets to detect population expansion. Mol. Biol. Evol. 16: 453-466.

Rempel, L.L., and Smith, D.G. 1998. Postglacial fish dispersal from the Mississippi refuge to the Mackenzie River basin. Can. J. Fish. Aquat. Sci. 55: 893-899. doi:10.1139/cjfas-55-4-893.

Rhymer, J.M., Fain, M.G., Austin, J.E., Johnson, D.H., and Krajewski, C. 2001. Mitochondrial phylogeography, subspecific taxonomy, and conservation genetics of sandhill cranes (Grus canadensis; Aves: Gruidae). Conserv. Genet. 2: 203-218. doi:10.1023/A:1012203532300.

Rice, W. 1989. Analyzing tables of statistical tests. Evolution, 43: 223-225. doi:10.2307/2409177.

Rousset, F. 1997. Genetic differentiation and estimation of gene flow from $F$-statistics under isolation by distance. Genetics, 145: 1219-1228. PMID:9093870.

Rozas, J., Sánchez-DelBarrio, J.C., Messeguer, X., and Rozas, R. 2003. DnaSP, DNA polymorphism analyses by the coalescent and other methods. Bioinformatics, 19: 2496-2497. doi:10. 1093/bioinformatics/btg359. PMID:14668244.

Sanetra, M., and Meyer, A. 2005. Microsatellites from the burbot (Lota lota), a freshwater gadoid fish (Teleostei). Mol. Ecol. Notes, 5: 390-392. doi:10.1111/j.1471-8286.2005.00937.x.

Schluter, D. 2000. The ecology of adaptive radiations. Oxford University Press Inc., New York.

Schneider, S., Roessli, D., and Excoffier, L. 2000. Arlequin ver. 2.000: a software for population genetics data analysis. Genetics and Biometry Laboratory, University of Geneva, Switzerland.

Snyder, D.E. 1979. Burbot - larval evidence for more than one North American species? In Proceedings of the Third Symposium on Larval Fishes. Edited by R.D. Hoyt. Western Kentucky University, Department of Biology, Bowling Green, Kentucky. pp. 204-220.

Stamford, M.D., and Taylor, E.B. 2004. Phylogeographical lineages of Arctic grayling (Thymallus arcticus) in North America: divergence, origins and affinities with Eurasian Thymallus. Mol. 
Ecol. 13: 1533-1549. doi:10.1111/j.1365-294X.2004.02174.x. PMID:15140096.

Taylor, E.B., Tamkee, P., Sterling, G., and Hughson, W. 2007. Microsatellite DNA analysis of rainbow trout (Oncorhynchus mykiss) from western Alberta, Canada: native status and evolutionary distinctiveness of "Athabasca" rainbow trout. Conserv. Genet. 8: 1-15. doi:10.1007/s10592-006-9142-9.

Templeton, A.R., Crandall, K.A., and Sing, C.F. 1992. A cladistic analysis of phenotypic associations with haplotypes inferred from restriction endonuclease mapping and DNA sequence data. III. Cladogram estimation. Genetics, 132: 619-633. PMID: 1385266.

Thompson, J.D., Gibson, T.J., Plewniak, F., Jeanmougin, F., and Higgins, D.G. 1997. The CLUSTAL_X windows interface: flexible strategies for multiple sequence alignment aided by quality analysis tools. Nucleic Acids Res. 25: 4876-4882. doi:10.1093/ nar/25.24.4876. PMID:9396791.

Turgeon, J., and Bernatchez, L. 2001. Mitochondrial DNA phylogeography of lake cisco (Coregonus artedi): evidence supporting extensive secondary contacts between two glacial races. Mol. Ecol. 10: 987-1001. doi:10.1046/j.1365-294X.2001.01248.x. PMID:11348505.

Utter, F. 2001. Patterns of subspecific anthropogenic introgression in two salmonid genera. Rev. Fish Biol. Fish. 10: 265-279. doi:10.1023/A:1016686415022.

Van Houdt, J.K., Hellemans, B., and Volckaert, F.A.M. 2003. Phylogenetic relationships among Palearctic and Nearctic burbot (Lota lota): Pleistocene extinctions and recolonization. Mol. Phylogenet. Evol. 29: 599-612. doi:10.1016/S1055-7903(03) 00133-7. PMID:14615196.

Van Houdt, J.K.J., de Cleyn, L., Perretti, A., and Volckaert, F.A.M. 2005. A mitogenic view on the evolutionary history of the Holarctic freshwater gadoid, burbot (Lota lota). Mol. Ecol. 14: 2445-2457. doi:10.1111/j.1365-294X.2005.02590.x. PMID: 15969726.

Van Houdt, J.K., De Cleyn, L., Perretti, A., and Volckaert, F.A.M. 2006. Discriminating glacial races of burbot (Lota lota) by means of PCR-RF-SSCP (PRS) analysis of the mitochondrial control region. Mol. Ecol. Notes, 6: 554-558. doi:10.1111/j. 1471-8286.2006.01268.x.

Wilson, C.C., and Hebert, P.D.N. 1996. Phylogeographic origins of lake trout (Salvelinus namaycush) in eastern North America. Can. J. Fish. Aquat. Sci. 53: 2764-2775. doi:10.1139/ cjfas-53-12-2764.

Wilson, C.C., and Hebert, P.D.N. 1998. Phylogeography and postglacial dispersal of lake trout (Salvelinus namaycush) in North America. Can. J. Fish. Aquat. Sci. 55: 1010-1024. doi:10.1139/ cjfas-55-4-1010.

Wilson, C.C., Hebert, P.D.N., Reist, J.D., and Dempson, J.B. 1996. Phylogeography and postglacial dispersal of Arctic charr Salvelinus alpinus in North America. Mol. Ecol. 5: 187-197. doi:10. 1111/j.1365-294X.1996.tb00306.x.
Wootton, R.J. 1991. Ecology of teleost fishes. Kluwer Academic Publishers, Boston, Mass.

Wright, S. 1978. Evolution and the genetics of populations. Vol. 4. Variability within and among natural populations. University of Chicago Press, Chicago, Illinois.

\section{Appendix A}

Fig. A1. Mismatch distributions for (a) L. l. maculosa and (b) L. $l$. lota. In both cases, the observed frequency of pairwise differences (solid histogram) is not significantly different than the simulated expectation (shaded line) under sudden expansion. Lota l. maculosa: $\tau=6.10, \theta_{0}=0.63, \theta_{1}=21.68$, estimated mean number of pairwise differences $=5.46 ;$ L. l. lota: $\tau=2.00, \theta_{0}=1.36, \theta_{1}=$ 999999.00, estimated mean number of pairwise differences $=$ 3.13 .

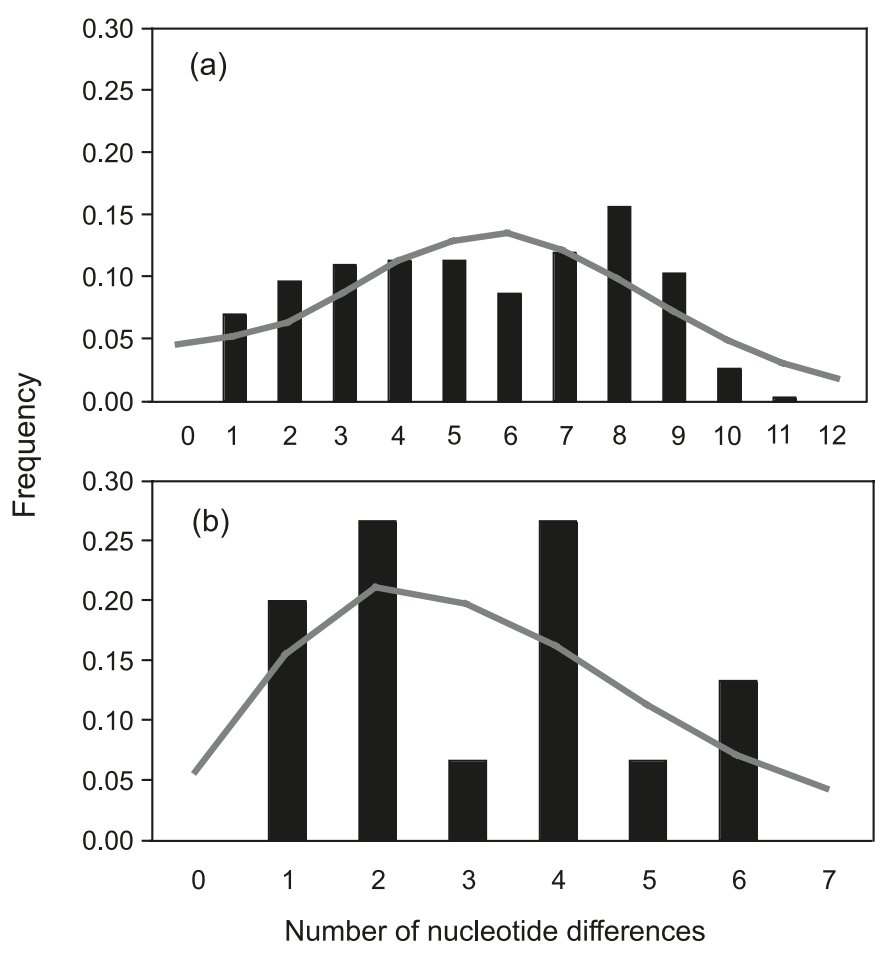

\section{Appendix B}

Figure B1 appears on the next page. 


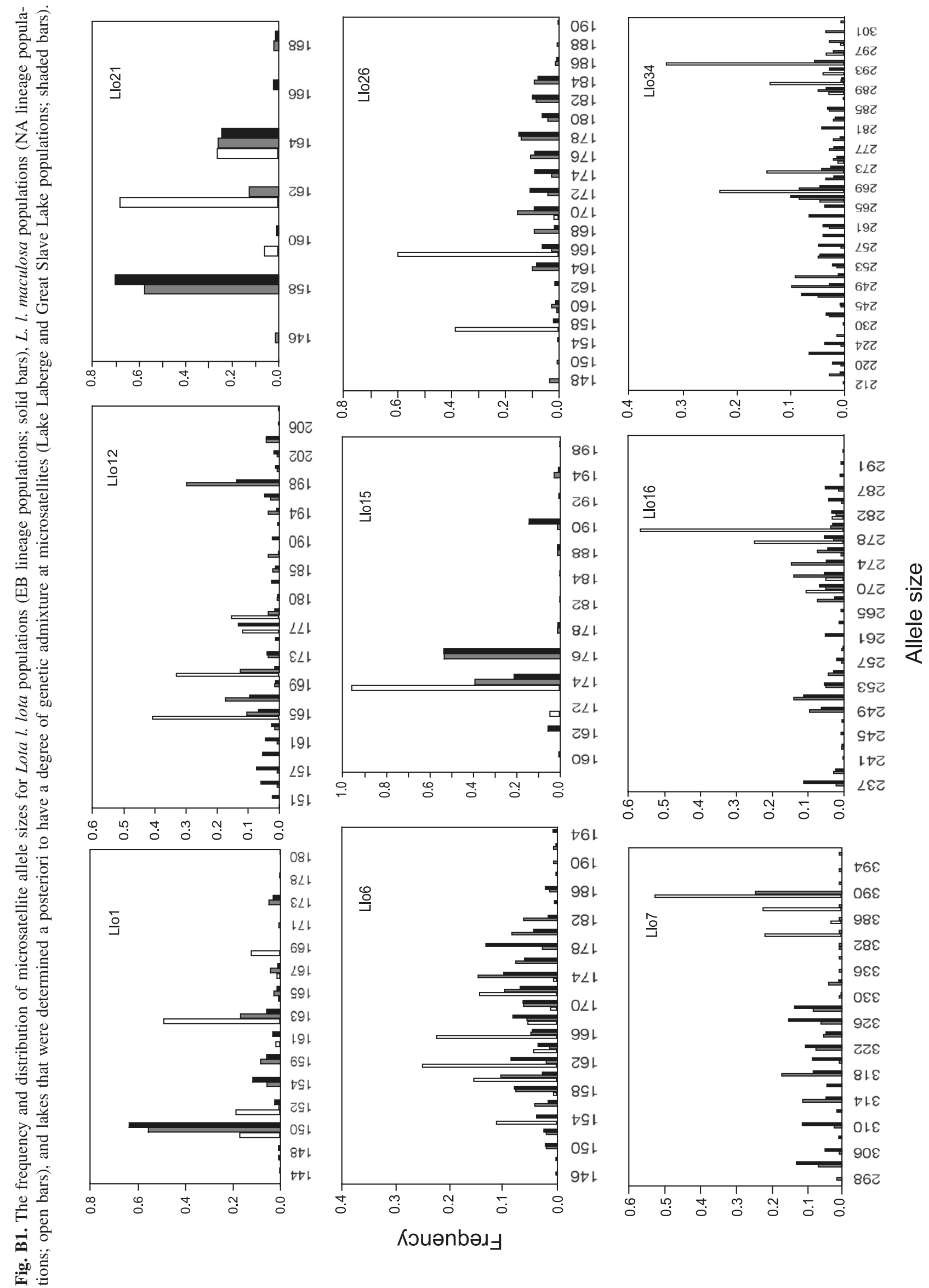

